\title{
Erratum to: Update with level 1 studies of the European Hernia Society guidelines on the treatment of inguinal hernia in adult patients
}

\author{
M. Miserez $\cdot$ E. Peeters $\cdot$ T. Aufenacker $\cdot$ J. L. Bouillot $\cdot$ G. Campanelli \\ J. Conze $\cdot$ R. Fortelny $\cdot$ T. Heikkinen $\cdot$ L. N. Jorgensen $\cdot$ J. Kukleta $\cdot$ \\ S. Morales-Conde $\cdot$ P. Nordin $\cdot$ V. Schumpelick $\cdot$ S. Smedberg $\cdot$ \\ M. Smietanski • G. Weber • M. P. Simons
}

Published online: 30 April 2014

(C) Springer-Verlag France 2014

\section{Erratum to: Hernia (2014) 18:151-163 \\ DOI 10.1007/s10029-014-1236-6}

The original publication of this article unfortunately contained the wrong figure 2 (page 154). The correct figure is shown below.

The online version of the original article can be found under doi:10.1007/s10029-014-1236-6.

\section{Miserez $(\bowtie) \cdot$ E. Peeters}

Department of Abdominal Surgery, University Hospitals

Leuven, Herestraat 49, 3000 Leuven, Belgium

e-mail: marc.miserez@uzleuven.be

\section{T. Aufenacker}

Department of Surgery, Rijnstate Hospital, PO Box 9555,

6800 TA Arnhem, The Netherlands

\section{J. L. Bouillot}

Department of General, Digestive and Metabolic Surgery,

Ambroise Paré Teaching Hospital, 9, Avenue Charles de Gaulle,

92100 Boulogne, France

\section{G. Campanelli}

University of Insubria, Via Quadronno, 29, 20122 Milan, Italy

J. Conze

Hernienzentrum, Arabellastrabe 7, 81925 Munich, Germany

R. Fortelny

Department of General, Visceral and Oncological Surgery,

Wilhelminenspital, 1171 Vienna, Austria
T. Heikkinen

Oulu University Hospital, Otavansakara 7, 90630 Oulu, Finland

L. N. Jorgensen

Digestive Disease Center, Bispebjerg Hospital, University of Copenhagen, 2400 Copenhagen, NV, Denmark

J. Kukleta

Department of Surgery, Klinik Im Park, Grossmuensterplatz 9, 8001 Zurich, Switzerland

S. Morales-Conde

University Hospital Sevilla, Betis 65, 41010 Seville, Spain

P. Nordin

Department of Surgical and Perioperative Science, Umeå

University, 90187 Umeå, Sweden

V. Schumpelick

Falkensteiner Ufer 34, 22587 Hamburg, Germany 


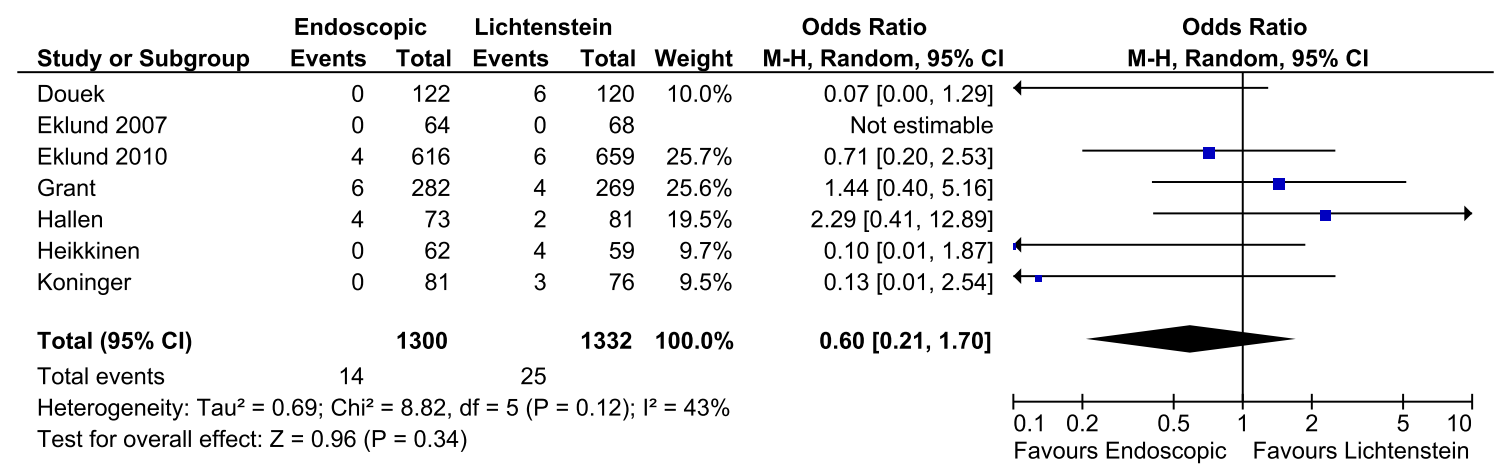

Fig. 2 Pooled data of seven studies on severe chronic pain with follow-up $>4$ years after endoscopic vs. Lichtenstein inguinal hernia repair

S. Smedberg

Department of Surgery, Helsingborg/Ängelholm Hospital,

Ängelholm, Sweden

M. Smietanski

Department of General and Vascular Surgery, Ceynowa

Hospital, Jagalskiego 10, 84-200 Wejherowo, Poland

G. Weber

Department of Surgical Research and Techniques, Semmelweis

University, 1089 Budapest, Hungary

M. P. Simons

Onze Lieve Vrouwe Hospital, Postbus 95500,

1040 HM Amsterdam, The Netherlands 